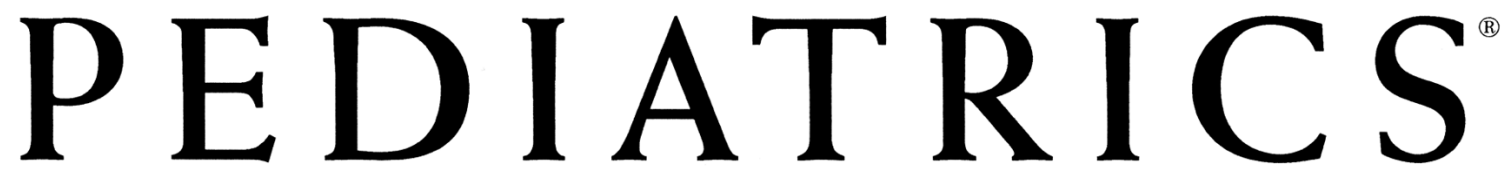

OFFICIAL JOURNAL OF THE AMERICAN ACADEMY OF PEDIATRICS

\title{
Use of Spanking for 3-Year-Old Children and Associated Intimate Partner Aggression or Violence
}

Catherine A. Taylor, Shawna J. Lee, Neil B. Guterman and Janet C. Rice

Pediatrics published online Aug 23, 2010;

DOI: $10.1542 /$ peds.2010-0314

The online version of this article, along with updated information and services, is located on the World Wide Web at:

http://www.pediatrics.org

PEDIATRICS is the official journal of the American Academy of Pediatrics. A monthly publication, it has been published continuously since 1948. PEDIATRICS is owned, published, and trademarked by the American Academy of Pediatrics, 141 Northwest Point Boulevard, Elk Grove Village, Illinois, 60007. Copyright (O 2010 by the American Academy of Pediatrics. All rights reserved. Print ISSN: 0031-4005. Online ISSN: 1098-4275.

\section{American Academy of Pediatrics}

DEDICATED TO THE HEALTH OF ALL CHILDREN ${ }^{\mathrm{m}}$ 


\section{Use of Spanking for 3-Year-0ld Children and Associated Intimate Partner Aggression or Violence}

AUTHORS: Catherine A. Taylor, PhD, MSW, MPH, ${ }^{\text {a Shawna }}$ J. Lee, PhD, MSW, MPP, ${ }^{\mathrm{b}}$ Neil B. Guterman, PhD, ${ }^{\mathrm{c}}$ and Janet C. Rice, $\mathrm{PhD}^{\mathrm{d}}$

aDepartment of Community Health Sciences, and ${ }^{d}$ Department of Biostatistics, School of Public Health and Tropical Medicine, Tulane University, New Orleans, Louisiana; ${ }^{b}$ Merrill-Palmer Skillman Institute for Child and Family Development, School of Social Work, Wayne State University, Detroit, Michigan; ${ }^{\circ}$ School of Social Service Administration and Chapin Hall Center for Children, University of Chicago, Chicago, Illinois

\section{KEY WORDS}

corporal punishment, physical punishment, spank, parenting, domestic violence, intimate partner aggression or violence, toddlers, epidemiology

\section{ABBREVIATIONS}

$\mathrm{CP}$-corporal punishment

IPAV - intimate partner aggression or violence

FFCWS-Fragile Families and Child Wellbeing Study

The views in this article are those of the authors and do not necessarily represent the views of the Centers for Disease Control and Prevention or the Eunice Kennedy Shriver National Institute of Child Health and Human Development.

www.pediatrics.org/cgi/doi/10.1542/peds.2010-0314

doi:10.1542/peds.2010-0314

Accepted for publication Jun 1, 2010

Address correspondence to Catherine A. Taylor, PhD, MSW, MPH, Tulane University School of Public Health and Tropical Medicine, Department of Community Health Sciences, 1440 Canal St, Suite 2301 TW19, New Orleans, LA 70112. E-mail: ctaylor5@tulane.edu PEDIATRICS (ISSN Numbers: Print, 0031-4005; Online, 1098-4275). Copyright (C) 2010 by the American Academy of Pediatrics FINANCIAL DISCLOSURE: The authors have indicated they have no financial relationships relevant to this article to disclose.
WHAT'S KNOWN ON THIS SUBJECT: CP is associated with risk for harm to children yet has a high prevalence and high approval ratings in the United States. Very few studies have assessed the co-occurrence of IPAV and CP.

WHAT THIS STUDY ADDS: This study describes CP and associated IPAV in families by using a population-based sample and reports from both mothers and fathers. It also specifies who aggressed against the child, assessed 5 patterns of cooccurrence, and examined alternative explanations for co-occurrence.

OBJECTIVES: The objective of this study was to examine associations between maternal and paternal use of corporal punishment (CP) for 3-year-old children and intimate partner aggression or violence (IPAV) in a population-based sample.

METHODS: The study sample $(N=1997)$ was derived from wave 3 of the Fragile Families and Child Wellbeing Study. Mother and father reports regarding their use of $\mathrm{CP}$ and their IPAV victimization were analyzed. IPAV included coercion and nonphysical and physical aggression.

RESULTS: Approximately $65 \%$ of the children were spanked at least once in the previous month by 1 or both parents. Of couples who reported any family aggression (87\%), 54\% reported that both CP and IPAV occurred. The most prevalent patterns of co-occurrence involved both parents as aggressors either toward each other (ie, bilateral IPAV) or toward the child. The presence of bilateral IPAV essentially doubled the odds that 1 or both parents would use $\mathrm{CP}$, even after controlling for potential confounders such as parenting stress, depression, and alcohol or other drug use. Of the 5 patterns of cooccurring family aggression assessed, the "single aggressor" model, in which only 1 parent aggressed in the family, received the least amount of empirical support.

CONCLUSIONS: Despite American Academy of Pediatrics' recommendations against the use of CP, CP use remains common in the United States. CP prevention efforts should carefully consider assumptions made about patterns of co-occurring aggression in families, given that adult victims of IPAV, including even minor, nonphysical aggression between parents, have increased odds of using $\mathrm{CP}$ with their children. Pediatrics 2010;126:415-424 
Despite the fact that the American Academy of Pediatrics does not recommend the use of corporal punishment (CP) for children, ${ }^{1,2}$ CP has high approval ratings ${ }^{3}$ and high prevalence rates in the United States. ${ }^{4-6} \mathrm{CP}$ has been linked with many poor outcomes for children, including poorer mental health and parent-child relationships and increased aggressive behavior,? with the latter being true even after controlling for other parenting risks and the child's initial level of aggression. ${ }^{8} \mathrm{CP}$ also is associated with increased odds of child maltreatment, ${ }^{6}$ particularly child physical abuse. 7,9

Although much attention has been paid to determining risk factors and patterns of child maltreatment, less attention has been paid to determining risk for CP. CP and child maltreatment share many of the same risk factors, including parenting stress, depression, use of alcohol or other drugs, and consideration of aborting the child. $6,8,10$ Parents also are more likely to use CP when they experienced $\mathrm{CP}$ during their own childhood ${ }^{11,12}$; believe that it will lead to positive outcomes ${ }^{13,14}$; have positive attitudes or beliefs toward it ${ }^{12,14-16}$; or perceive approval of CP use by experts, family, or friends. ${ }^{14}$ Risk for using $\mathrm{CP}$ may increase with approval or use of other types of coercion, aggression, or violence in the family as well.

Many studies have examined the cooccurrence of intimate partner aggression or violence (IPAV) and child physical abuse (e.g., see reference ${ }^{17}$ ), but few have examined co-occurring IPAV and CP specifically. One populationbased study is a notable exception: Slep and $0^{\prime}$ Leary ${ }^{18}$ found that almost $90 \%$ of families reported using CP with children and/or some form of physical aggression between intimate partners, which included mild physical aggression such as pushing or grabbing; and of those families, $51 \%$ reported

1) Single aggressor: only one parent aggressed against the other parent and the child

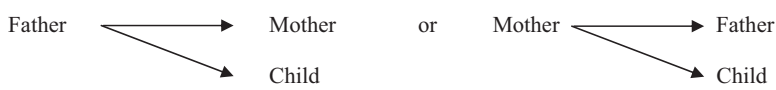

2) Sequential aggressors: only one parent aggressed against the other parent and only the victimized parent aggressed against the child

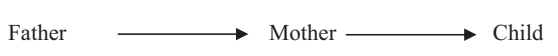

or

Mother $\longrightarrow$ Father $\longrightarrow$ Child

3) Unilateral IPAV / dual CP aggressors: only one parent aggressed against the other parent and both parents aggressed against the child

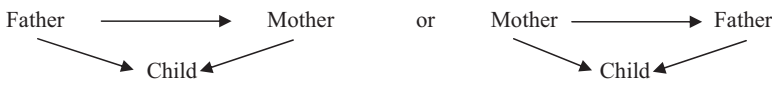

4) Bilateral IPAV / single CP aggressor: both parents aggressed against each other and only one parent aggressed against the child

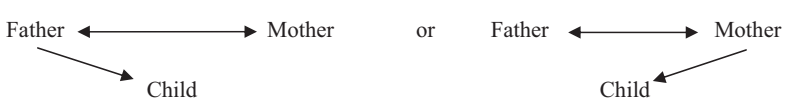

5) Bilateral IPAV / dual CP aggressors: both parents aggressed against each other and against the child

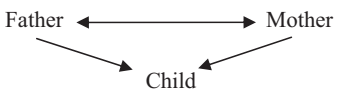

FIGURE 1

Five patterns of co-occurring IPAV and CP of the index child assessed in this study. Bilateral IPAV does not mean that there was equivalence between adults in terms of fault or potential for harm.

both IPAV and aggression toward the child. The most common pattern of cooccurring family aggression that they found involved bilateral IPAV (ie, both parents aggressed against each other) in conjunction with both parents' aggressing against the child. ${ }^{18}$ Although multiple patterns of cooccurring family aggression might be discerned in a population, ${ }^{17}$ most previous studies of co-occurring family aggression or violence have made assumptions about a single IPAV aggressor, usually an adult male, and have not specified who aggressed against the child (e.g., see references ${ }^{19-21}$ ).

In this study, we aimed to expand on this previous literature to understand better the patterns of family aggression and risk for use of CP. First, we assessed the prevalence of the following 5 patterns of co-occurring IPAV and use of $\mathrm{CP}$ on the basis of reports from both parents: (1) single aggressor; (2) sequential aggressors; (3) unilateral IPAV/dual CP aggressors; (4) bilateral IPAV/single CP aggressor; and)5) bilateral IPAV/dual CP aggressors (Fig 1). Second, we examined associations between IPAV patterns and patterns of $\mathrm{CP}$ use within families. Understanding such patterns and associated risks within a population-based sample may have important implications for CP and child abuse prevention interventions.

\section{METHODS}

\section{Study Sample}

The Fragile Families and Child Wellbeing Study (FFCWS) is a national longitudinal cohort study of families in 20 US cities with populations of $>200000$. For each family or case $(n=4898)$, baseline data were collected for the mother, father, and index child at or near the time of the index child's birth, 
with additional waves of data collected when the index child was 1,3 , and 5 years of age. Interviews were available in English or Spanish. This secondary data analysis was considered exempt by the institutional review board at Tulane University Health Sciences Center; however, the FFCWS protocol was approved by the institutional review boards at Princeton and Columbia Universities, the FFCWS home institutions. A complete description of the FFCWS sampling strategy and design is documented elsewhere. ${ }^{22}$

The study sample included only families for which mothers and fathers both completed interviews when the index child was 3 years of age ( $n=$ 3165). Compared with those who did not complete the 3 -year interview ( $n=$ 1733), these parents were more likely to be married and these mothers were more likely to be older, more educated, and white and have a higher income and a nonmissing response for religion; they were less likely to be foreignborn or have considered aborting the child. (When comparable father data were available, the same trends held.) Because of the centrality of both the CP and IPAV variables in this study, families also had to meet the following eligibility criteria to be included in this study (number of dropped cases for each criterion is listed): (1) both parents had to have seen the child within the past 30 days before the interview (a requirement for being asked about their use of CP with the child; $n=273$ ); (2) neither parent could have a "missing" response to the CP question ( $n=$ 12); (3) both parents had to report being either married or romantically involved with each other at the wave 3 interview (a requirement for being asked about their IPAV victimization by the other parent; $n=870$ ); and (4) neither parent could have "missing" responses to all of the IPAV questions $(n=13)$. A final sample of 1997 fami- lies met all of the study eligibility criteria.

Table 1 shows descriptive characteristics for all families who completed interviews at wave 3 along with statistics showing that, on the basis of most of the assessed characteristics, families who were included in this study were statistically different from those who were excluded. Characteristics that are more common in the excluded group are associated with higher overall risk for IPAV and CP (Table 2); this is because the 2 main exclusion criteria (either parent not seeing the child at least once in the past month and parents' being no longer romantically involved) both are associated with higher risk family characteristics.

\section{Variables}

All variables were based on mother and father self-reports and were assessed when the index child was 3 years of age, with the exception of some demographics and a question about consideration of abortion, which were assessed at baseline. All childrelated variables refer to the index child.

\section{Corporal Punishment}

$\mathrm{CP}$ was assessed with a question that asked each parent whether he or she had spanked the child in the past month for misbehaving or acting up and was coded as neither parent (0), only mother (1), only father (2), or both parents (3) spanked the index child at least once in the past month.

\section{Intimate Partner Aggression or Violence}

IPAV victimization by the other parent was assessed by using 7 items. Three items were adapted from the Conflict Tactics Scale ${ }^{23}$ to assess physical violence and coercion: slaps or kicks you; hits you with a fist or an object that could hurt you; and tries to make you have sex or do sexual things you don't want to do. Four items were adapted from studies by Lloyd ${ }^{24}$ and the Spouse Observation Checklist ${ }^{25}$ to assess psychological aggression and coercion: tries to keep you from seeing or talking with your friends or family; tries to prevent you from going to work or school; withholds/makes you ask for/ takes your money; and insults or criticizes you. A binary variable was created for each parent that indicated whether the parent had reported experiencing any type of IPAV victimization by the other parent.* These 2 variables were combined to create the final IPAV variable, which was coded as neither parent (0), only mother (1), only father (2), or both parents (3) reported any type of IPAV victimization by the other parent.

\section{Covariates}

Other parenting risk factors and family demographics were chosen for inclusion in this study on the basis of previous evidence suggesting an association between these variables and CP. $6,8,26,27$

Parenting stress was assessed by using 4 items from the Parenting Stress Index, ${ }^{28}$ which measured the extent to which mothers ( $\alpha=.61)$ and fathers $(\alpha=.63)$ agreed (from $0=$ strongly disagree to $3=$ strongly agree) with statements such as, "Being a parent is harder than I thought it would be." Each variable was coded as an average score for the 4 items.

Presence of depression and use of alcohol or other drugs were assessed by using the Composite International Diagnostic Interview-Short Form, a standardized instrument that is widely used and has documented reliability and validity. ${ }^{29}$ Scoring for depression was based on diagnostic criteria set forth in the Diagnostic and Statistical Manual of Mental Disorders, Fourth Edition. ${ }^{30} \mathrm{~A}$ parent was coded positively for use of alcohol or drugs when he or 
TABLE 1 Descriptive and Bivariate Statistics of Family Characteristics for the Entire FFCWS Sample Interviewed During Wave 3 (2001-2004), When the Child Was 3 Years of Age, by Inclusion Versus Exclusion From This Study

\begin{tabular}{|c|c|c|c|c|}
\hline Parameter & $\begin{array}{c}\text { Total FFCWS } \\
\text { Wave } 3 \text { Sample } \\
(n=3165)\end{array}$ & $\begin{array}{l}\text { Included in } \\
\text { This Study } \\
(n=1997)\end{array}$ & $\begin{array}{l}\text { Excluded From } \\
\text { This Study } \\
(n=1168) \\
\end{array}$ & $P$ \\
\hline \multicolumn{5}{|l|}{ Parenting risk factors } \\
\hline \multicolumn{5}{|l|}{ Parenting stress score, mean \pm SD } \\
\hline Mother (range: 0-3) & $1.24 \pm 0.7$ & $1.21 \pm 0.6$ & $1.30 \pm 0.7$ & $<.001$ \\
\hline Father (range: 0-3) & $1.07 \pm 0.7$ & $1.07 \pm 0.7$ & $1.08 \pm 0.7$ & NS \\
\hline \multicolumn{5}{|l|}{ Major depression, \% } \\
\hline Mother & 20.3 & 16.0 & 27.5 & $<.001$ \\
\hline Father & 14.2 & 10.6 & 20.5 & $<.001$ \\
\hline \multicolumn{5}{|l|}{ Use of alcohol or other drugs, \% } \\
\hline Mother & 15.4 & 14.4 & 17.1 & $<.050$ \\
\hline Father & 35.1 & 35.0 & 35.3 & NS \\
\hline \multicolumn{5}{|l|}{ Considered aborting this child, \% } \\
\hline Mother & 26.0 & 19.7 & 36.8 & $<.001$ \\
\hline Father & 14.3 & 11.9 & 18.5 & $<.001$ \\
\hline Father's report of ever being in jail, \% & 21.8 & 14.3 & 34.6 & $<.001$ \\
\hline \multicolumn{5}{|l|}{ Family demographics } \\
\hline Child gender (boy), \% & 52.1 & 52.7 & 52.1 & NS \\
\hline \multicolumn{5}{|l|}{ Age, mean $\pm S D, y$} \\
\hline Mother & $28.5 \pm 6.1$ & $29.6 \pm 6.2$ & $26.6 \pm 5.5$ & $<.001$ \\
\hline Father & $31.1 \pm 7.3$ & $32.0 \pm 7.1$ & $29.4 \pm 7.4$ & $<.001$ \\
\hline Education, mother, \% & & & & $<.001$ \\
\hline Less than high school & 31.5 & 27.5 & 38.4 & $<.001$ \\
\hline High school & 29.6 & 27.3 & 33.7 & $<.001$ \\
\hline Some college & 25.6 & 26.5 & 24.1 & NS \\
\hline College graduate & 13.1 & 18.6 & 3.7 & $<.001$ \\
\hline \multicolumn{5}{|l|}{ Race/ethnicity, \% } \\
\hline Mother & & & & $<.001$ \\
\hline Black & 46.3 & 35.6 & 64.5 & $<.001$ \\
\hline Hispanic & 25.4 & 30.2 & 17.3 & $<.001$ \\
\hline White & 24.0 & 29.1 & 15.4 & $<.001$ \\
\hline Other & 4.0 & 4.8 & 2.7 & $<.010$ \\
\hline Father & & & & $<.001$ \\
\hline Black & 48.6 & 38.0 & 66.8 & $<.001$ \\
\hline Hispanic & 25.1 & 29.7 & 17.0 & $<.001$ \\
\hline White & 22.0 & 27.3 & 12.8 & $<.001$ \\
\hline Other & 3.8 & 4.5 & 2.6 & $<.010$ \\
\hline \multicolumn{5}{|l|}{ Foreign-born, \% } \\
\hline Mother & 15.2 & 21.1 & 5.1 & $<.001$ \\
\hline Father & 14.7 & 19.6 & 6.3 & $<.001$ \\
\hline \multicolumn{5}{|l|}{ Religion, \% } \\
\hline Mother & & & & $<.001$ \\
\hline Catholic & 27.9 & 33.7 & 18.0 & $<.001$ \\
\hline Protestant & 38.6 & 36.5 & 42.3 & .001 \\
\hline Other Christian & 12.4 & 10.4 & 15.9 & $<.001$ \\
\hline No religious preference & 16.0 & 14.1 & 19.2 & $<.001$ \\
\hline Other & 4.1 & 4.7 & 3.1 & $<.050$ \\
\hline Father & & & & $<.001$ \\
\hline Catholic & 34.2 & 40.8 & 32.8 & $<.001$ \\
\hline Protestant & 32.7 & 25.7 & 34.3 & NS \\
\hline Other Christian & 9.2 & 7.2 & 8.5 & $<.001$ \\
\hline No religious preference & 16.8 & 17.8 & 16.6 & $<.001$ \\
\hline Other & 6.9 & 6.5 & 7.5 & NS \\
\hline $\begin{array}{l}\text { Mother and father are married, } \% \\
\text { Income, natural log of annual household, } \\
\text { mean } \pm \text { SD, } \$\end{array}$ & 38.5 & 59.2 & 3.1 & $<.001$ \\
\hline Mother (range 0.0-13.8) & $10.0 \pm 1.3$ & $10.3 \pm 1.2$ & $9.5 \pm 1.3$ & $<.001$ \\
\hline Father (range $0.0-13.8$ ) & $10.1 \pm 1.9$ & $10.5 \pm 1.2$ & $9.4 \pm 2.5$ & $<.001$ \\
\hline
\end{tabular}

Missing data for each variable equaled $\leq 1 \%$, except for the following father variables: parenting stress (8.4\%), consideration of abortion (10.3\%), and foreign-born status (10.1\%). Bivariate associations were examined by using Pearson $\chi^{2}$ tests (for binary and categorical variables) or 1-way analyses of variance (for continuous variables). Actual income data were as follows: for mothers, mean $=\$ 39200($ SD $=\$ 47222)$; for fathers, mean $=\$ 46012($ SD $=\$ 53593)$. she had used any of 9 possible substances or had 4 drinks in 1 day within the past year. Detailed methods for scoring these items are described elsewhere. ${ }^{31}$

Remaining covariates included whether each parent considered abortion of the index child, whether the father had ever spent any time in jail or prison, and a set of family demographic variables that included the child's gender and the following demographics for both parents: age, education level, race/ethnicity, nativity, religion, marital status, and annual household income.

\section{Statistical Analyses}

Frequency distributions were generated for all study variables. Bivariate associations were examined by using $\chi^{2}$ tests, analyses of variance, or Kruskal-Wallis tests of medians as appropriate and as indicated in Tables 1 and 2. Patterns of IPAV and CP were identified by using tabulation and combining appropriate cells (Table 3). Table 4 presents 2 multinomial regression models that were developed to obtain unadjusted (model 1) and adjusted (model 2) odds ratios of IPAV (4-category predictor; reference group = "neither parent") associated with parental use of CP (4-category outcome; reference group = "neither parent"). Model 2 included all covariates described already (under "Variables") and shown in Table 1. Multicollinearity was not a problem: the mean variance inflation factor was 2.6.

Use of weighted data is preferred in presenting population prevalence (Table 3). National weights were available for 1427 cases and allowed for sample design adjustment, lack of response at baseline, and loss to follow-up at wave 3. National weights were unavailable for cases from the 4 cities that were not randomly selected ( $n=513)$ as well as for cases that were not randomly selected at the 
TABLE 2 Descriptive and Bivariate Statistics of Family Characteristics by Use of CP: FFCWS, 2001-2004

\begin{tabular}{|c|c|c|c|c|c|c|}
\hline Parameter & $\begin{array}{l}\text { Total Sample } \\
\qquad(N=1997)\end{array}$ & $\begin{array}{l}\text { No Parent Used } \\
\mathrm{CP}(n=693)\end{array}$ & $\begin{array}{l}\text { Only Mother Used } \\
\qquad \mathrm{CP}(n=469)\end{array}$ & $\begin{array}{l}\text { Only Father Used } \\
\text { CP }(n=254)\end{array}$ & $\begin{array}{l}\text { Both Parents Used } \\
\text { CP }(n=581)\end{array}$ & $P$ \\
\hline \multicolumn{7}{|l|}{ Parenting risk factors } \\
\hline \multicolumn{7}{|l|}{ Parenting stress score, median $(95 \% \mathrm{Cl})$} \\
\hline Mother (range: 0-3) & $1.3(1.3-1.3)$ & $1.0(1.0-1.3)$ & $1.3(1.3-1.3)$ & $1.0(1.0-1.0)$ & $1.3(1.3-1.3)$ & $<.001$ \\
\hline Father (range: $0-3$ ) & $1.0(1.0-1.0)$ & $1.0(0.8-1.0)$ & $1.0(1.0-1.0)$ & $1.0(1.0-1.0)$ & $1.0(1.0-1.3)$ & $<.001$ \\
\hline \multicolumn{7}{|l|}{ Major depression, \% } \\
\hline Mother & 16.0 & 12.0 & 20.0 & 13.4 & 18.6 & $<.001$ \\
\hline Father & 10.6 & 9.1 & 10.3 & 9.1 & 13.3 & NS \\
\hline \multicolumn{7}{|l|}{ Use of alcohol or other drugs, $\%$} \\
\hline Mother & 14.4 & 10.9 & 15.4 & 12.2 & 18.8 & $<.010$ \\
\hline Father & 35.0 & 29.6 & 33.6 & 34.4 & 42.7 & $<.001$ \\
\hline \multicolumn{7}{|l|}{ Considered aborting this child, \% } \\
\hline Mother & 19.7 & 15.7 & 24.3 & 18.9 & 20.7 & $<.010$ \\
\hline Father & 11.9 & 7.5 & 14.9 & 13.4 & 14.1 & $<.001$ \\
\hline \multicolumn{7}{|l|}{ Father ever in jail, \% } \\
\hline Mother's report & 22.1 & 18.0 & 25.4 & 24.4 & 23.4 & $<.050$ \\
\hline Father's report & 14.3 & 11.7 & 14.7 & 16.2 & 16.4 & \\
\hline \multicolumn{7}{|l|}{ Family demographics } \\
\hline Child gender (boy), \% & 52.7 & 47.8 & 50.1 & 58.3 & 58.4 & $<.001$ \\
\hline \multicolumn{7}{|l|}{ Age, median $(95 \% \mathrm{Cl})$, y } \\
\hline Mother (range: 17-48) & $29(28-29)$ & $30(29-31)$ & $28(27-29)$ & $27(26-29)$ & $28(28-29)$ & $<.001$ \\
\hline Father (range: 18-71) & $31(31-32)$ & $33(32-33)$ & $31(30-32)$ & $30(29-31)$ & $31(30-31)$ & $<.001$ \\
\hline \multicolumn{7}{|l|}{ Education, \% } \\
\hline \multicolumn{7}{|l|}{ Mother } \\
\hline Less than high school & 27.5 & 30.5 & 28.8 & 31.9 & 21.0 & $<.001$ \\
\hline High school & 27.3 & 24.5 & 27.3 & 29.9 & 29.4 & NS \\
\hline Some college & 26.5 & 21.9 & 28.6 & 26.4 & 30.5 & $<.010$ \\
\hline College graduate & 18.6 & 23.1 & 15.4 & 11.4 & 19.1 & $<.001$ \\
\hline Father & & & & & & $<.001$ \\
\hline Less than high school & 28.5 & 30.6 & 32.8 & 29.9 & 21.9 & $<.001$ \\
\hline High school & 29.2 & 25.5 & 29.2 & 28.7 & 33.9 & $<.050$ \\
\hline Some college & 24.0 & 19.6 & 23.5 & 26.8 & 28.6 & $<.010$ \\
\hline College graduate & 17.6 & 22.9 & 14.0 & 14.6 & 15.5 & $<.001$ \\
\hline \multicolumn{7}{|l|}{ Race/ethnicity, \% } \\
\hline Mother & & & & & & $<.001$ \\
\hline Black & 35.6 & 26.8 & 40.9 & 35.4 & 41.8 & $<.001$ \\
\hline Hispanic & 30.2 & 37.5 & 29.2 & 33.9 & 20.7 & $<.001$ \\
\hline White & 29.1 & 29.6 & 25.8 & 26.0 & 32.5 & NS \\
\hline Other & 4.8 & 5.6 & 3.8 & 4.3 & 4.8 & NS \\
\hline Father & & & & & & $<.001$ \\
\hline Black & 38.0 & 29.2 & 41.2 & 39.4 & 45.3 & $<.001$ \\
\hline Hispanic & 29.7 & 35.9 & 29.0 & 34.7 & 20.8 & $<.001$ \\
\hline White & 27.3 & 29.0 & 25.2 & 22.1 & 29.4 & NS \\
\hline Other & 4.5 & 5.5 & 4.3 & 3.5 & 4.0 & NS \\
\hline \multicolumn{7}{|l|}{ Foreign-born, \% } \\
\hline Mother & 21.1 & 31.1 & 20.1 & 19.7 & 10.7 & $<.001$ \\
\hline Father & 19.6 & 29.4 & 19.8 & 16.5 & 9.0 & $<.001$ \\
\hline \multicolumn{7}{|l|}{ Religion, \% } \\
\hline \multicolumn{6}{|l|}{ Mother } & $<.001$ \\
\hline Catholic & 33.7 & 41.0 & 32.2 & 39.8 & 23.4 & $<.001$ \\
\hline Protestant & 36.5 & 29.7 & 36.3 & 33.5 & 46.0 & $<.001$ \\
\hline Other Christian & 10.4 & 7.8 & 11.5 & 9.1 & 13.1 & $<.050$ \\
\hline No religious preference & 14.1 & 14.4 & 15.6 & 14.6 & 12.2 & NS \\
\hline Other & 4.7 & 6.4 & 4.3 & 2.0 & 4.1 & $<.050$ \\
\hline Father & & & & & & $<.001$ \\
\hline Catholic & 34.2 & 40.8 & 32.8 & 37.0 & 26.0 & $<.001$ \\
\hline Protestant & 32.7 & 25.7 & 34.3 & 31.5 & 40.3 & $<.001$ \\
\hline Other Christian & 9.2 & 7.2 & 8.5 & 11.8 & 11.0 & $<.050$ \\
\hline No religious preference & 16.8 & 17.8 & 16.6 & 15.8 & 16.2 & NS \\
\hline Other & 6.5 & 7.8 & 6.6 & 2.8 & 6.4 & .050 \\
\hline $\begin{array}{l}\text { Mother and father are married (vs romantically } \\
\text { involved but not married), \% }\end{array}$ & 59.2 & 59.6 & 53.3 & 57.1 & 64.5 & $<.010$ \\
\hline $\begin{array}{l}\text { Income, natural log of annual household, } \\
\text { median }(95 \% \mathrm{CI}), \$\end{array}$ & & & & & & \\
\hline Mother (range: $0.0-13.8$ ) & $10.5(10.5-10.5)$ & $10.5(10.3-10.5)$ & $10.4(10.3-10.5)$ & $10.6(10.5-10.7)$ & $10.5(10.5-10.5)$ & NS \\
\hline Father (range: $0.0-13.8$ ) & $10.6(10.5-10.6)$ & $10.5(10.5-10.6)$ & $10.5(10.5-10.6)$ & $10.5(10.5-10.6)$ & $10.7(10.6-10.8)$ & NS \\
\hline
\end{tabular}

Missing data for each variable equaled $\leq 1 \%$, except that father's consideration of abortion and father's foreign-born status each had $7.3 \%$ missing. Bivariate associations were examined by using Pearson $\chi^{2}$ tests (for binary and categorical variables) or Kruskal-Wallis tests (for continuous variables). Actual income data were as follows: for mothers, mean $=\$ 48776$ ( $\mathrm{SD}=$ $\$ 54$ 242); for fathers, mean $=\$ 53456($ SD $=\$ 57076)$. Cl indicates confidence interval.

level of hospital or birth $(n=57) .32$ Weighted data are representative of births between 1998 and 2000 in large
US cities (ie, those with populations of $>200000$ persons in 1994) ${ }^{32}$ for families who met the study eligibility crite- ria. Although most of the analyses conducted took advantage of the full sample $(N=1997)$, we also presented 
TABLE 3 Patterns of IPAV and Parental Use of CP Within Families by Using Unweighted and Weighted Data: FFCSW, 2001-2004

\begin{tabular}{|c|c|c|c|c|}
\hline \multirow[t]{2}{*}{ Parameter } & \multicolumn{2}{|c|}{$\begin{array}{l}\text { Unweighted } \\
(n=1997)\end{array}$} & \multicolumn{2}{|c|}{$\begin{array}{l}\text { Weighted } \\
(n=1427)\end{array}$} \\
\hline & $\begin{array}{l}\text { Totals Within } \\
\text { Patterns, \% }\end{array}$ & $\begin{array}{c}\text { Totals for Each } \\
\text { Pattern, \% }\end{array}$ & $\begin{array}{l}\text { Totals Within } \\
\text { Patterns, \% }\end{array}$ & $\begin{array}{c}\text { Totals for Each } \\
\text { Pattern, \% }\end{array}$ \\
\hline \multicolumn{5}{|l|}{ Co-occurring IPAV and CP } \\
\hline Single aggressor & & 6.2 & & 4.0 \\
\hline Dad to mom/dad to child & 1.3 & & 0.5 & \\
\hline Mom to dad/mom to child & 4.9 & & 3.5 & \\
\hline Sequential aggressors & & 9.6 & & 6.0 \\
\hline Dad to $\mathrm{mom} / \mathrm{mom}$ to child & 5.7 & & 3.1 & \\
\hline Mom to dad/dad to child & 3.9 & & 2.9 & \\
\hline Bilateral IPAV/single CP aggressor & & 11.0 & & 14.6 \\
\hline Both adults/dad to child & 3.9 & & 6.8 & \\
\hline Both adults/mom to child & 7.1 & & 7.8 & \\
\hline Unilateral IPAV/dual CP aggressors & & 12.9 & & 12.6 \\
\hline Dad to mom/both parents & 4.1 & & 2.7 & \\
\hline Mom to dad/both parents & 8.8 & & 9.9 & \\
\hline Bilateral IPAV/dual CP aggressors & & 9.1 & & 8.7 \\
\hline Total & & 48.8 & & 45.9 \\
\hline \multicolumn{5}{|l|}{ Non co-occurring IPAV and CP } \\
\hline IPAV only & & 22.0 & & 21.3 \\
\hline Unilateral IPAV (dad to mom) & 5.4 & & 6.4 & \\
\hline Unilateral IPAV (mom to dad) & 8.9 & & 8.9 & \\
\hline Bilateral IPAV & 7.7 & & 6.0 & \\
\hline CP only & & 16.7 & & 18.2 \\
\hline Single aggressor CP (dad to child) & 3.7 & & 2.6 & \\
\hline Single aggressor CP (mom to child) & 5.8 & & 4.1 & \\
\hline Dual aggressor CP & 7.2 & & 11.5 & \\
\hline Total & & 38.7 & & 39.5 \\
\hline No IPAV or CP reported & & 12.7 & & 14.7 \\
\hline Total & & 100.0 & & 100.0 \\
\hline
\end{tabular}

weighted data ( $n=1427$ ) for prevalence patterns shown in Table 3. Because sampling weights can make regression analyses highly inefficient, we instead used unweighted data but accounted for the main cluster variables (city and marital status at birth) in the multinomial regression models (Table 4) as recommended by Korn and Graubard. 33

\section{RESULTS}

Descriptive and bivariate statistics for risk factors and demographics by parents' use of CP are presented in Table 2. Approximately $65 \%$ of children in the sample were spanked by 1 or both parents in the previous month: $12.7 \%$ by the father only, $23.5 \%$ by the mother only, and $29.1 \%$ by both parents. All examined parenting risks were positively associated with use of CP. Parents who were older, Hispanic, foreign-born, or Catholic had lowerthan-average risk for using CP; parents who were black had higherthan-average risk. Being married or protestant increased the risk for both parents' using CP.

IPAV was reported in $\sim 71 \%$ of the families: $27.7 \%$ reported bilateral and $42.9 \%$ reported unilateral IPAV. Table 3 shows very similar patterns of IPAV and CP use across unweighted and weighted data; only the latter are discussed herein given their greater generalizability to a broader population. Most (85\%) families reported the presence of IPAV, CP, or both, with the majority of these families reporting both. Each of the 5 proposed patterns of cooccurring IPAV and CP was present: bilateral IPAV/single CP aggressor was most common (15\%) followed by unilateral IPAV/dual CP aggressors (13\%), bilateral IPAV/dual CP aggressors (9\%), sequential aggressors (6\%), and single aggressor (4\%).

Unadjusted (model 1) and adjusted (model 2) multinomial odds ratios of IPAV associated with CP use are presented in Table 4; only model 2 is described herein. Compared with when there was no IPAV present, mothers who acted alone had nearly 2.5 times the odds of using CP when the mother was the only IPAV victim and nearly double the odds when bilateral IPAV was present. Fathers who acted alone had $\sim 1.6$ times the odds of using $\mathrm{CP}$ when the father was the only IPAV victim and 2.2 times the odds when bilateral IPAV was present. The odds for both parents' using CP were almost double when either parent was the only IPAV victim and more than double when both parents were IPAV victims.

There are some noteworthy patterns of association between family characteristics and CP use. Parenting stress was consistently associated with CP use for each parent. Alcohol or other drug use by either parent significantly raised the odds of both parents' using CP. The odds of a parent's using CP were greater for boys than for girls. Finally, black parents and US-born fathers had increased odds of using CP. (Note: Ninety percent of parents were cohabiting; when examined, cohabitation status was not associated with either CP or IPAV in either bivariate or regression analyses.)

\section{DISCUSSION}

This study examined co-occurrence of IPAV and CP within families. In a literature review focused on the cooccurrence of more severe aggression within families (IPAV and child physical abuse), the following recommendations were made for future studies, which are relevant for the current inquiry: (1) use population-based over clinical samples; (2) examine alternative explanations for co-occurrence 
TABLE 4 Two Multinomial Regressions (Unadjusted and Adjusted) of IPAV Associated With Parental Use of CP: FFCWS, 2001-2004

\begin{tabular}{|c|c|c|c|c|c|c|}
\hline \multirow{2}{*}{$\frac{\text { Parameter }}{\text { Model 1: unadjusted ORs }(n=1997)}$} & \multicolumn{2}{|c|}{ Only Mother Used CP } & \multicolumn{2}{|c|}{ Only Father Used CP } & \multicolumn{2}{|c|}{ Both Parents Used CP } \\
\hline & OR & $95 \% \mathrm{Cl}$ & OR & $95 \% \mathrm{Cl}$ & OR & $95 \% \mathrm{Cl}$ \\
\hline Neither parent victim (reference) & 1.00 & & 1.00 & & 1.00 & \\
\hline Mother only victim & 2.32 & $1.79-3.00^{\mathrm{a}}$ & 0.83 & $0.47-1.48$ & 1.36 & $0.91-2.04$ \\
\hline Father only victim & 1.18 & $0.87-1.60$ & 1.47 & $1.02-2.12^{\mathrm{c}}$ & 1.75 & $1.27-2.40^{\mathrm{b}}$ \\
\hline Both parents victims & 2.02 & $1.43-2.85^{\mathrm{a}}$ & 1.72 & $1.22-2.41^{\mathrm{b}}$ & 2.09 & $1.44-3.02^{\mathrm{a}}$ \\
\hline \multicolumn{7}{|l|}{$\begin{array}{l}\text { Model 2: adjusted ORs }(n=1977) \\
\text { IPAV }\end{array}$} \\
\hline Neither parent victim (reference) & 1.00 & & 1.00 & & 1.00 & \\
\hline Mother only victim & 2.47 & $1.92-3.19^{\mathrm{a}}$ & 1.10 & $0.65-1.86$ & 1.84 & $1.15-2.93^{c}$ \\
\hline Father only victim & 1.21 & $0.83-1.76$ & 1.57 & $1.13-2.19^{b}$ & 1.83 & $1.28-2.63^{\mathrm{b}}$ \\
\hline Both parents victims & 1.92 & $1.29-2.88^{\mathrm{b}}$ & 2.21 & $1.57-3.12^{\mathrm{a}}$ & 2.23 & $1.50-3.30^{\mathrm{a}}$ \\
\hline \multicolumn{7}{|l|}{ Parenting stress, PSI score } \\
\hline Mother & 1.44 & $1.14-1.84^{b}$ & 0.89 & $0.67-1.17$ & 1.37 & $1.09-1.71^{\mathrm{b}}$ \\
\hline Father & 1.07 & $0.86-1.34$ & 1.25 & $1.03-1.53^{\mathrm{c}}$ & 1.29 & $1.07-1.56^{\mathrm{b}}$ \\
\hline \multicolumn{7}{|l|}{ Major depression } \\
\hline Mother & 1.45 & $1.00-2.09$ & 0.98 & $0.65-1.47$ & 1.18 & $0.87-1.55$ \\
\hline Father & 0.90 & $0.55-1.45$ & 0.76 & $0.42-1.42$ & 1.08 & $0.81-1.45$ \\
\hline \multicolumn{7}{|l|}{ Use of alcohol or other drugs } \\
\hline Mother & 1.23 & $0.80-1.93$ & 0.99 & $0.67-1.46$ & 1.51 & $1.15-1.99^{\mathrm{b}}$ \\
\hline Father & 1.16 & $0.83-1.63$ & 1.10 & $0.80-1.53$ & 1.63 & $1.18-2.26^{\mathrm{b}}$ \\
\hline \multicolumn{7}{|l|}{ Considered aborting this child } \\
\hline Mother & 1.01 & $0.79-1.28$ & 0.82 & $0.53-1.30$ & 0.81 & $0.59-1.14$ \\
\hline Father & 1.64 & $1.20-2.23^{\mathrm{b}}$ & 1.47 & $0.78-2.72$ & 1.43 & $0.87-2.31$ \\
\hline \multicolumn{7}{|l|}{ Father ever in jail } \\
\hline Mother's report & 1.23 & $0.83-1.83$ & 1.11 & $0.73-1.56$ & 1.06 & $0.79-1.36$ \\
\hline \multicolumn{7}{|l|}{ Family demographics } \\
\hline Child gender, boy & 1.20 & $1.01-1.42^{\mathrm{c}}$ & 1.73 & $1.27-2.35^{\mathrm{a}}$ & 1.69 & $1.42-2.02^{\mathrm{a}}$ \\
\hline Age & & & & & & \\
\hline Mother & 0.97 & $0.95-0.99^{\mathrm{c}}$ & 0.99 & $0.95-1.02$ & 0.98 & $0.96-1.00$ \\
\hline Father & 1.00 & $0.98-1.03$ & 0.97 & $0.94-1.01$ & 0.97 & $0.94-0.99^{c}$ \\
\hline Education & & & & & & \\
\hline Mother & & & & & & \\
\hline Less than high school (reference) & 1.00 & & 1.00 & & 1.00 & \\
\hline High school & 1.11 & $0.81-1.48$ & 0.91 & $0.64-1.30$ & 1.34 & $0.86-2.05$ \\
\hline Some college & 1.27 & $0.90-1.79$ & 0.86 & $0.60-1.24$ & 1.50 & $0.94-2.38$ \\
\hline College graduate & 0.78 & $0.52-1.17$ & 0.35 & $0.19-0.62^{\mathrm{a}}$ & 1.04 & $0.54-1.99$ \\
\hline Father & & & & & & \\
\hline Less than high school (reference) & 1.00 & & 1.00 & & 1.00 & \\
\hline High school & 0.84 & $0.61-1.13$ & 1.03 & $0.77-1.33$ & 1.22 & $0.88-1.66$ \\
\hline Some college & 0.84 & $0.62-1.10$ & 1.41 & $0.92-2.03$ & 1.27 & $0.90-1.75$ \\
\hline College graduate & 0.52 & $0.36-0.76^{\mathrm{b}}$ & 1.11 & $0.56-2.17$ & 0.66 & $0.41-1.08$ \\
\hline Race/ethnicity of parents & & & & & & \\
\hline Black (reference) & 1.00 & & 1.00 & & 1.00 & \\
\hline Hispanic & 0.58 & $0.41-0.82^{\mathrm{b}}$ & 0.59 & $0.37-0.98^{c}$ & 0.49 & $0.32-0.78^{\mathrm{b}}$ \\
\hline White & 0.70 & $0.51-0.97^{\mathrm{c}}$ & 0.61 & $0.41-0.94^{\mathrm{C}}$ & 0.57 & $0.36-0.91^{\mathrm{c}}$ \\
\hline Other & 0.90 & $0.52-1.75$ & 0.91 & $0.44-1.99$ & 0.97 & $0.41-2.28$ \\
\hline Mixed & 0.58 & $0.35-0.97^{\mathrm{c}}$ & 0.66 & $0.37-1.26$ & 0.75 & $0.50-1.11$ \\
\hline Foreign-born (vs US-born) & & & & & & \\
\hline Mother & 0.81 & $0.49-1.30$ & 0.90 & $0.52-1.51$ & 0.72 & $0.47-1.09$ \\
\hline Father & 0.83 & $0.57-1.21$ & 0.47 & $0.24-0.90^{c}$ & 0.40 & $0.23-0.67^{\mathrm{b}}$ \\
\hline Religion & & & & & & \\
\hline Mother & & & & & & \\
\hline Protestant (reference) & 1.00 & & 1.00 & & 1.00 & \\
\hline Catholic & 0.90 & $0.61-1.35$ & 1.28 & $0.75-2.17$ & 0.64 & $0.42-0.99^{c}$ \\
\hline Other Christian & 1.11 & $0.76-1.65$ & 0.91 & $0.54-1.57$ & 1.02 & $0.67-1.53$ \\
\hline No religious preference & 0.81 & $0.58-1.13$ & 0.84 & $0.59-1.20$ & 0.57 & $0.38-0.87^{\mathrm{b}}$ \\
\hline Other & 0.68 & $0.37-1.27$ & 0.73 & $0.24-2.23$ & 0.68 & $0.35-1.32$ \\
\hline Father & & & & & & \\
\hline Protestant (reference) & 1.00 & & 1.00 & & 1.00 & \\
\hline Catholic & 0.83 & $0.56-1.23$ & 0.91 & $0.51-1.57$ & 0.80 & $0.60-1.07$ \\
\hline Other Christian & 0.81 & $0.50-1.32$ & 1.26 & $0.74-2.00$ & 1.01 & $0.56-1.82$ \\
\hline No religious preference & 0.68 & $0.46-1.00$ & 0.66 & $0.38-1.15$ & 0.59 & $0.38-0.92^{c}$ \\
\hline Other & 0.90 & $0.42-1.95$ & 0.38 & $0.10-2.01$ & 0.89 & $0.45-1.76$ \\
\hline $\begin{array}{l}\text { Mother and father are married (vs romantically } \\
\text { involved but not married) }\end{array}$ & 1.08 & $0.76-1.53$ & 1.28 & $0.77-2.05$ & 1.68 & $1.22-2.33^{b}$ \\
\hline Annual household income & & & & & & \\
\hline Mother & 1.01 & $0.88-1.16$ & 0.95 & $0.85-1.06$ & 0.95 & $0.85-1.06$ \\
\hline Father & 1.19 & $1.01-1.39^{c}$ & 1.12 & $0.99-1.27$ & 1.08 & $0.95-1.24$ \\
\hline
\end{tabular}

Model 1 is an unadjusted (bivariate) analysis of IPAV (4 categories; reference = "neither parent IPAV victim") by CP (4 categories; reference = "neither parent used CP"). Model 2 is an adjusted (multivariate) analysis of IPAV by CP, adjusted for all parenting risk and demographic characteristics described in Table 2 . Both models were adjusted for 2 key variables used in the sampling design: marital status at birth (married or unmarried) and city. Missing data for each variable equaled $\leq 1 \%$, except that father's consideration of abortion and father's foreign-born status each had $7.3 \%$ missing. OR indicates odds ratio; Cl, confidence interval; PSI, Parenting Stress Index.

a $P<.001$.

b $P<.01$.

c $P<.05$. 
(eg, account for potential confounders); (3) use multiple informants including reports by fathers; (4) specify who aggressed against the child; and (5) "the greatest need is to test the different models of co-occurrence." ( $p$. $595)^{17}$ In our previous study of cooccurrence, which looked at IPAV and $\mathrm{CP}$ as well as child physical abuse, psychological abuse, and neglect, we found support for a "sequential aggressors" model (father to mother and mother to child aggression); however, we addressed only recommendations 1 and 2 above. ${ }^{6}$ This study aimed to address all 5 noted recommendations with a primary focus on assessing multiple models of co-occurrence. We found the "single aggressor" model to be least prevalent; and consistent with similar studies, ${ }^{18,34}$ patterns involving both parents as aggressors were most prevalent.

The presence of even minor forms of aggression between parents, such as criticism and controlling behaviors, were linked with increased odds of using $\mathrm{CP}$ with young children. These findings may be explained, in part, through Patterson's ${ }^{35}$ theory of coercive family process, a theory that is based in operant conditioning and suggests that family aggression may escalate from initial small aversive events and that such escalation occurs via positive reinforcement. ${ }^{36}$ This process suggests that escalation of aggression between a dyad is likely, lending support to our finding that the single aggressor pattern was least prevalent. Also relevant is Bandura's ${ }^{37}$ social cognitive theory, which focuses on the importance of observational learning and the normalization of behavior within a particular environment and supports empirical findings regarding an intergenerational cycle of IPAV. ${ }^{38}$ This study and others ${ }^{18,39}$ suggested an intrafamilial cycle of aggression in which bilateral IPAV is associated with in- creased risk for parental aggression directed toward a child. The adult IPAV victim, in particular, has increased odds of using $\mathrm{CP}$.

The current study has some important limitations. First is the dichotomization of IPAV and CP and the cross-sectional nature of the data point to the need for future studies that provide a more nuanced understanding of these linkages. We did not differentiate in terms of the context, severity, chronicity, sequencing, or escalation of family aggression over time. This level of detail would aid in developing a more precise model of cooccurring family aggression and risk.

Second, the questions used to assess IPAV were not comprehensive in assessing all forms of IPAV40; however, given that verbal aggression is more common than physical aggression among families who are at risk for maltreatment $^{34}$ as well as in population-based samples, this measure may be more relevant for informing efforts to prevent $\mathrm{CP}$ than 1 that is more inclusive of more physical and severe forms of violence.

Third, all study variables were based on self-reports, which may be subject to recall, social desirability, and other types of bias; however, parents needed only to recall any use of CP within the previous month, which should have helped to minimize recall bias for that key variable.

Finally, although this study took into account many key covariates and potential confounders, some important ones may be missing. Of particular importance is the lack of information regarding both parents' exposure to violence and aggression in their families of origin. Other unmeasured potential confounders are mentioned in the second paragraph of the introduction.

\section{CONCLUSIONS}

Even minor forms of aggression and conflict between parents, such as criticism and controlling behaviors, were linked with increased odds of parents' using CP with young children. Given the American Academy of Pediatrics's recommendations regarding $\mathrm{CP}$ and the risks that $\mathrm{CP}$ poses to children, pediatricians who are concerned with even minor aggression between parents might also be concerned with parental discipline strategies in such families. Assumptions of "single aggressor" patterns within families may be detrimental to the child given that adult victims of IPAV have increased odds of using $\mathrm{CP}$ with their children. Assessments of family aggression and violence should consider and explore the multiple complex patterns of family aggression that are possible. Efforts to promote positive, noncoercive, and nonviolent communication and conflict resolution between parents may reduce the odds of parents' using $\mathrm{CP}$ and thereby reduce risk for additional harm to the child.

\section{ACKNOWLEDGMENTS}

This research was supported by grant R49CE000915-02 from the Centers for Disease Control and Prevention. The Fragile Families and Child Wellbeing Study (FFCWS) was supported by grants R01HD041141-02 and R0IHD36916 from the Eunice Kennedy Shriver National Institute of Child Health and Human Development.

We thank the FFCWS staff, data collectors, and administrators for data and study information management and organization. Thanks also to Ransome Eke for organization of literature for this study and also to the 1997 participants who gave their time and information for this study as well as the peer reviewers. 
*Physical violence also was examined separately; however, reports were too rare to draw any mean-

\section{REFERENCES}

1. Guidance for effective discipline. American Academy of Pediatrics. Committee on Psychosocial Aspects of Child and Family Health [published correction appears in $P e$ diatrics. 1998;102(2 pt 1):433]. Pediatrics. 1998;101 (4 pt 1):723-728

2. Healthy Children. Family life: where we stand — spanking. Elk Grove Village, IL: American Academy of Pediatrics; 2010. Available at: www.healthychildren.org/English/family-life/ family-dynamics/communication-discipline/ Pages/Where-We-Stand-Spanking.aspx. Accessed April 22, 2010

3. Survey USA. Disciplining a child 08/24/05. Verona, NJ: SurveyUSA; 2005. Available at: www.surveyusa.com/50StateDisciplineChild 0805SortedbyTeacher.htm. Accessed July 3 , 2009

4. Daro D. Public Opinion and Behaviors Regarding Child Abuse Prevention: 1999 Survey. Chicago, IL: Prevent Child Abuse America, National Center on Child Abuse Prevention Research; 1999

5. Straus MA, Stewart JH. Corporal punishment by American parents: national data on prevalence, chronicity, severity, and duration, in relation to child and family characteristics. Clin Child Fam Psychol Rev. 1999; 2(2): $55-70$

6. Taylor CA, Guterman NB, Lee SJ, Rathouz PJ. Intimate partner violence, maternal stress, nativity, and risk for maternal maltreatment of young children. Am J Public Health. 2009;99(1):175-183

7. Gershoff ET. Corporal punishment by parents and associated child behaviors and experiences: a meta-analytic and theoretical review. Psychol Bull. 2002;128(4): 539-579

8. Taylor CA, Manganello JA, Lee SJ, Rice J. Mothers' spanking of 3-year-old children and subsequent risk of children's aggressive behavior. Pediatrics. 2010; 125(5)Available at: www.pediatrics.org/cgi/ content/full/125/5/e1057

9. Zolotor AJ, Theodore AD, Chang JJ, Berkoff MC, Runyan DK. Speak softly_and forget the stick: corporal punishment and child physical abuse. Am J Prev Med. 2008;35(4): 364-369

10. Lee SJ, Perron B, Taylor CA, Guterman NB. Paternal psychosocial characteristics and corporal punishment of their 3-year-old children. J Interpers Violence. 2010, in press

11. Barkin S, Scheindlin B, Ip EH, Richardson I, ingful conclusions from multivariate analyses or for practice-based implications.

Finch S. Determinants of parental discipline practices: a national sample from primary care practices. Clin Pediatr (Phila). 2007; 46(1):64-69

12. Socolar RR, Stein RE. Spanking infants and toddlers: maternal belief and practice. $P e$ diatrics. 1995;95(1):105-111

13. Holden GW, Miller PC, Harris SD. The instrumental side of corporal punishment: parents' reported practices and outcome expectancies. Journal of Marriage and the Family. 1999;61 (4):908-919

14. Taylor CA, Hamvas L, DeJong W, Rice JC. Normative Beliefs, Expectations, and Use of Corporal Punishment: Findings From an RDD Community Survey. Philadelphia, PA: American Public Health Association; 2009. Available at: http://apha.confex.com/apha/ 137 am/webprogram/Paper197696.html. Accessed July 15, 2010

15. Vittrup B, Holden GW, Buck J. Attitudes predict the use of physical punishment: a prospective study of the emergence of disciplinary practices. Pediatrics. 2006;117(6):2055-2064

16. Holden GW, Coleman SM, Schmidt KL. Why 3-year-old children get spanked: parent and child determinants as reported by collegeeducated mothers. Merrill-Palmer Quarterly. 1995;41(4):431-452

17. Appel AE, Holden GW. The co-occurrence of spouse and physical child abuse: a review and appraisal. J Fam Psychol. 1998;12 (4):578-599

18. Slep AM, O'Leary SG. Parent and partner violence in families with young children: rates, patterns, and connections. J Consult Clin Psychol. 2005;73(3):435-444

19. Hartley CC. The co-occurrence of child maltreatment and domestic violence: examining both neglect and child physical abuse. Child Maltreat. 2002;7 (4):349-358

20. Hazen AL, Connelly CD, Kelleher K, Landsverk J, Barth R. Intimate partner violence among female caregivers of children reported for child maltreatment. Child Abuse Negl. 2004;28(3): 301-319

21. Tajima EA. Risk factors for violence against children: comparing homes with and without wife abuse. J Interpersonal Violence. 2002;17(2):122-149

22. Reichman NE, Teitler J0, Garfinkel I, McLanahan SS. Fragile families: sample and design. Children and Youth Services Review. 2001;23(4/5):303-326

23. Straus M, Hamby S, Boney-McCoy S, Sugarman D. The Revised Conflict Tactics Scale (CTS2): development and preliminary psy- chometric data. Journal of Family Issues. 1996;17(3):283-316

24. Lloyd SA. Physical aggression, distress, and everyday marital interactions. In: Cahn DD, Lloyd SA, eds. Family Violence From a Communication Perspective. Thousand Oaks, CA: Sage Publications Inc; 1996:177-198

25. Weiss RL, Margolin G. Assessment of marital conflict and accord. In: Ciminero AR, Calhoun KD, Adams HE, eds. Handbook of Behavioral Assessment. New York, NY: John Wiley; 1977:555-602

26. Gershoff ET, Miller PC, Holden GW. Parenting influences from the pulpit: religious affiliation as a determinant of parental corporal punishment. J Fam Psychol. 1999;13(3):307-320

27. Regalado M, Sareen H, Inkelas M, Wissow LS, Halfon N. Parents' discipline of young children: results from the National Survey of Early Childhood Health. Pediatrics. 2004; 113(6 suppl):1952-1958

28. R. Abidin Parent Stress Inventory. 3rd ed. Odessa, FL: Psychological Assessments Resources; 1995

29. Kessler RC, Andrews G, Mroczek D, Ustun TB, Wittchen HU. The World Health Organization Composite International Diagnostic Interview Short-Form (CIDI-SF). Int J Methods Psychiatr Res. 1998;7(4):171-185

30. American Psychiatric Association. Diagnostic and Statistical Manual of Mental Disorders. 4th ed. Washington, DC: American Psychiatric Association; 1994

31. Fragile families: scales documentation and question sources for 3-year questionnaires (scoring procedures for depression, pp. 5-8); 2006. Available at: www.fragilefamilies.princeton.edu/ documentation/core/scales/ff_3yr_scales. pdf. Accessed July 15, 2010

32. Fragile Families and Child Wellbeing Study: A Brief Guide to Using the Mother, Father, and Couple Replicate Weights for Core Telephone Surveys Waves 1-4; 2008. Available at: www.fragilefamilies.princeton.edu/ documentation/core/weights/using_ ffwǵts_rev0709.pdf. Accessed July 15, 2010

33. Korn EL, Graubard BI. Epidemiologic studies utilizing surveys: accounting for the sampling design. Am J Public Health. 1991;81(9):1166-1173

34. English DJ, Graham JC, Newton RR, et al. Atrisk and maltreated children exposed to intimate partner aggression/violence: what the conflict looks like and its relationship to child outcomes. Child Maltreat. 2009;14(2):157-171

35. Patterson GR. Coercive Family Process. 
Eugene, OR: Castalia Publishing Company; 1982

36. Robinson EA, Jacobson NS. Social learning theory and family psychopathology: a Kantian model of behaviorism? In: Jacob $\mathrm{T}$, ed. Family Interaction and Psychopathology. New York, NY Springer 1987: 117-162

37. Bandura A. Social Foundations of Thought and
Action: A Social Cognitive Theory. Englewood Cliffs, NJ: Prentice-Hall; 1986

38. Ehrensaft MK, Cohen P, Brown J, Smailes E, Chen H, Johnson JG. Intergenerational transmission of partner violence: a 20-year prospective study. J Consult Clin Psychol. 2003;71(4):741-753

39. Chang JJ, Theodore AD, Martin SL, Runyan DK. Psychological abuse between parents: associations with child maltreatment from a population-based sample. Child Abuse Negl. 2008;32(8):819-829

40. Centers for Disease Control and Prevention. Intimate partner violence prevention scientific information: definitions. Atlanta, GA: Centers for Disease Control and Prevention; 2008. Available at: www.cdc.gov/ncipc/dvp/IPV/ipvdefinitions.htm. Accessed January 26, 2010

\section{An Ancient Chinese Fungus Becomes an Oral Medication for Multiple Scle-}

rosis: In June, a Food and Drug Administration expert panel unanimously recommended that fingolimod be approved as the first oral medicine for treatment of multiple sclerosis. According to an article in The Wall Street Journal (Landers $P$, June 22, 2010), the drug is derived from a group of Asian fungi known in Chinese and Japanese as "winter-insect-summer plant." This fungus attacks insects in the winter killing them by summer so that their corpses can become repositories for more fungus to bloom. The fungus apparently stops the inflammatory response in the insect and this mechanism is thought to parallel what it can do in quieting an autoimmune reaction in a patient with multiple sclerosis. Trials to date have shown that it reduces the number of relapses in thousands of patients with the only side effects reported being a reduced heart rate on the first day of use and in rare cases swelling in the eye. The FDA is to make a final decision by the fall, and usually follows the recommendation of its expert panel. The drug's mechanism of action is not to destroy immune cells attacking the protective covering around nerve fibers, but to prevent immune cells from overreacting so they don't even rev up to go to the nerve fibers in the first place. More news on this drug will certainly be forthcoming in the months ahead.

Noted by JFL, MD 


\section{Use of Spanking for 3-Year-Old Children and Associated Intimate Partner Aggression or Violence}

Catherine A. Taylor, Shawna J. Lee, Neil B. Guterman and Janet C. Rice

Pediatrics published online Aug 23, 2010;

DOI: $10.1542 /$ peds. $2010-0314$

Updated Information

\& Services

Permissions \& Licensing

Reprints including high-resolution figures, can be found at:

http://www.pediatrics.org

Information about reproducing this article in parts (figures, tables) or in its entirety can be found online at:

http://www.pediatrics.org/misc/Permissions.shtml

Information about ordering reprints can be found online:

http://www.pediatrics.org/misc/reprints.shtml

\section{American Academy of Pediatrics}

